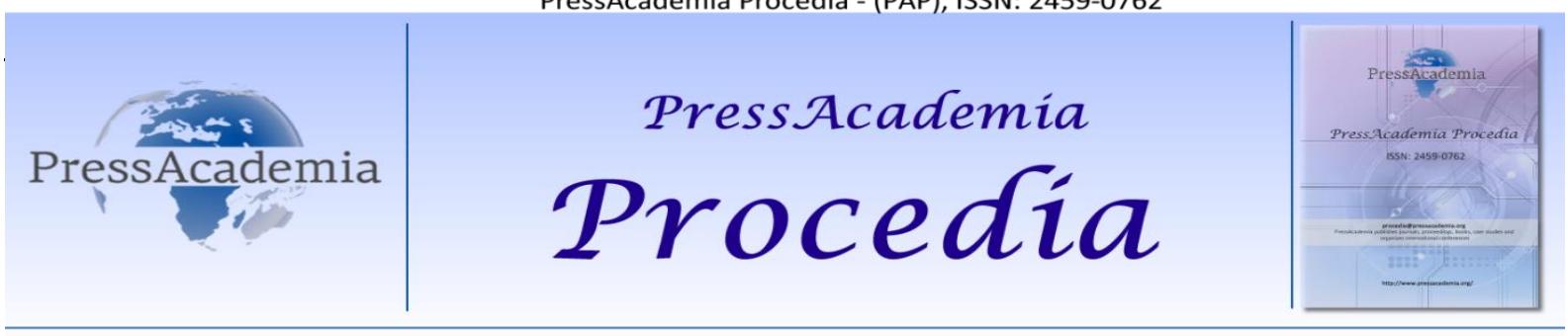

Global Business Research Congress (GBRC), May 24-25, 2017, Istanbul, Turkey.

\title{
INTELLECTUAL CAPITAL AND ITS IMPACT ON FIRM PERFORMANCE OF THE TURKISH FINANCIAL SECTOR BEFORE AND AFTER FINANCIAL CRISIS
}

\author{
DOI: 10.17261/Pressacademia.2017.674 \\ PAP-GBRC- V.3-2017(101)-p.916 \\ Emin Avci ${ }^{1}$, Sedeaq Nassar ${ }^{2}$ \\ ${ }^{1}$ Maramara University. eavci@marmara.edu.tr \\ ${ }^{2}$ Marmara University, sedeaq.nassar@gmail.com
}

\section{To cite this document}

Avci, E. and S. Nassar, (2017). Intellectual capital and its impact on firm performance of the Turkish financial sector before and after financial crisis. PressAcademia Procedia (PAP), V.3, p.916-

Permanant link to this document: $h \mathrm{ttp}: / /$ doi.org/10.17261/Pressacademia.2017.674

Copyright: Published by PressAcademia and limited licenced re-use rights only.

\begin{abstract}
The main purpose of this study is to investigate the relationship between intellectual capital and financial performance of financial companies listed in Borsa Istanbul, using data of 44 listed companies over 2004-2015. Value Added Intellectual Coefficient (VAIC) method is used as a measure of intellectual capital (IC). An OLS regression is utilized to examine the impact of intellectual capital; Human capital efficiency (HCE), Structural capital efficiency (SCE), and Capital employed efficiency (CEE) on market performance, financial performance, and productivity performance. The findings show that HCE has a positive significant relation with ROA after the crisis and with ROE before and after the crisis. SCE show a positive significant relation with PE and ROE after the crisis and a negative significant association with $\mathrm{MB}$ after the crisis. Regarding to $C E E$, the results show that it has only a positive significant impact on $M B$ after the crisis and a negative significant influence on ATO after the crisis. Generally, VAIC has a negative significant relationship with ATO before the crisis and has a positive association with ROA after the crisis, in addition to a positive significant influence of ROE before and after crisis.
\end{abstract}

Keywords: Intellectual capital, human capital, structural capital, capital employed, value added intellectual coefficient.

\section{INTRODUCTION}

Intellectual capital plays a significant role for value creation in today's economies and organizations, where organizations in knowledge-based economies have been depending on knowledge assets rather than tangible assets to enhance its competitive advantages (Hamzah \& Ismail, 2008)

According to the OECD (2008), several organizations enhance employee skills through training, research and development. They also invest in customer and supplier relations, technology, and information systems. Such actions, which are frequently called as intellectual capital investments, are increasing day by day on the expense of physical and financial capital investments. Such shift in investment behavior is attributable to the increasing attention to knowledge-based economies (Stewart, 2002; Zeghal \& Maaloul, 2010).

While knowledge can be described as information, alongside with the realization of how to use it (Mayo, 2001); Mårtensson (2000) defines knowledge management as the company's capability to manage and control the intellectual capital. Intellectual capital (IC) can be defined as the knowledge that can be converted into profit by exploiting the non-financial and nonphysical resources of the company (Sullivan, 1999).

It should be noted that there are numerous definitions available for intellectual capital. Several researchers have defined intellectual capital from a knowledge-based economy view and how intellectual capital contributes in maximizing value creation efficiency. The economic developments have led to significant changes in company's' operations on the global 
markets. Nowadays, we are witnessing an increasing focus to investment in intellectual resources, which enhances the competitive advantage of a company. This fact may cause the need to find a new way to manage and measure companies' performance through their intangible sources (Jurczak, 2008).

Several concepts like intellectual capital, intellectual assets, knowledge assets, and intangible assets can be used interchangeably (Bontis et al., 2000; Kujansivu \& Lönnqvist, 2007; Lev, 2001; Roos et al., 1997). Peppard \& Rylander (2001) argued that the combination of intellectual assets play a key role in creating value for the company. Similarly, Mavridis \& Kyrmizoglou (2005) pointed out the possible effects of intangible assets on value creation. Moreover, Edvinsson \& Malone (1997) said that the knowledge, information, and experience are the most important factors in value creation.

The financial sector is one of the most suitable areas for studying and researching IC because of the service and intellectual nature of the financial industry, which focuses mainly on knowledge and employee skills, more than financial and physical capital. In addition, this sector is known for its availability of reliable data (Mavridis, 2004). It is also believed that using IC in creating value in knowledge-based sectors, such as financial sector, is higher than other economic sectors (El-Bannany, 2008). The Turkish financial sector is considered as one of the most biggest sectors in Turkey and has a crucial role in economic development (Calisir et al., 2010).

The main objective of this study is to examine the relationship between intellectual capital and financial performance of financial companies listed in Borsa Istanbul before and after the financial crisis. The broad area of study, under which the paper falls in, is the area of market and productivity performance within the Intellectual Capital context.

\section{Intellectual Capital Definition}

Jon Kenneth Galbraith was the one, who introduced the intellectual capital in 1969 (Khalique, Shaari, Abdul, \& Isa, 2011). Although a long period of time has elapsed since its introduction, no consensus exists about its definition. However, the existing definitions are not considerably different from each other (Tayles et al., 2007). The vast majority of the definitions are essentially based on similar concepts like information, knowledge, experiences and skills of employees, customer and employees' loyalty and satisfaction, firm reputation, organizational systems and procedures, organizational cultures, and value creation (Barathi Kamath, 2007; Brooking, 1996; Edvinsson \& Malone, 1997; Roos \& Roos, 1997; Sullivan, 1999; Yalama \& Coskun, 2007), among others.

According to Edvinsson (1997); Kamath (2007); Pulic ( 2000); Roos et al. (1997); Stewart (1997); Sullivan (1999); Zeghal \& Maaloul (2010) IC is the company's intellectual ability, which presents how efficiently they use physical capital and intellectual potential to create value or how efficiently knowledge transformed into value. Moreover, Bontis et al. (2000); Brooking (1996); Roos \& Roos (1997); Sveiby (1997); Yalama \& Coskun (2007) stated that IC is the hidden resources which are not reported in financial statements, which also can be used as a competitive advantage and to maximize the future value of the company. In general, most definitions focus on how companies use knowledge (intangible sources) effectively to enhance a company's competitive advantage (or maximize the value of the firm).

\section{IC components}

Value Added Intellectual Coefficient (VAIC ${ }^{\text {TM }}$ ) method has been introduced by Ante Pulic (1997, 1998, 2001 and 2002 ). Pulic's approach is composed of three aspects of intellectual capital as Human Capital Efficiency (HCE), Structural Capital Efficiency (SCE), and Capital Employed Efficiency (CEE). Human Capital (HC) is considered as the most significant factor of innovation and competitiveness (Bozbura, 2004).

According to Pulic (1998 and 2008), HC is not only a collection of employees' characteristics, capabilities, skills, etc., but also, the value of invested capital in employees' knowledge (training, R\&D, wages, salaries, etc.) intellectual abilities, experiences, competencies of individual workers, which are not reflected in the financial statements (Chang, 2010; Edvinsson \& Malone, 1997; Meihami et al., 2013; Muhammad \& Ismail, 2009; Sullivan, 1999).

Structural capital (SC) defined as the organization's potential and capabilities in facing the internal and external challenges (Cabrita \& Vaz, 2005). Structural capital is the intellectual asset which is independent of individuals; hence, structural capital remains after employees leave the company (Chen et al., 2005; Sydler et al., 2014). Therefore, SC is considered as a nonhuman stock of knowledge, that includes each of the information technology, trademarks, patents, and plans, which can be represented by databases, software, hardware, and organizational structures (Al-Zoubi, 2013; Chen, et. al., 2005; Moradi et al., 2013).

Capital Employed (CE) is the tangible assets part of capital and contain both physical and financial assets. The physical part represent fixed assets and raw materials, while the financial part include other existing assets after employees leave the company (Basso et al., 2010). According to Pulic (2004), CE refers to physical and financial capital like book value of net assets. Similarly, Chen, et. al. (2005); Mosavi et. al. (2012); Rehman, et. al. (2014); Rehman, et. al. (2012) are calculated CE as the sum of physical and financial assets, or by deducting intangible assets from total assets. 


\section{LITERATURE REVIEW}

The first empirical study of intellectual capital has been conducted by Pulic (1998), which examine the effect of IC on firm performance. Pulic (1998) created a new method using accounting tools to measure IC and companies' financial performance. It has opened the way widely for researchers from many countries to measure IC efficiency for banking and other sectors (Abdulsalam et al., 2011). Bontis, (1998a) shed some light on the development of some terms and measurement models relating to IC and its effect on firm performance.. Luthy (1998) presented an operational definition of IC and a framework for classifying and identifying the various elements of intellectual capital. Moreover, the paper explored several methods measuring IC and its components, as well as, measurements of organizational levels.

Bontis et. al., (2000) studied the effects accounting IC components (HC, SC and relational capital) on performance of Malaysian service and non-service companies. They revealed that $\mathrm{HC}$ and relational capital have positive impact on the service sector. Another study conducted in Malaysia by Muhammad \& Ismail (2014) examined the effect of IC efficiency on performance of financial sectors. The results pointed out that the banking sector is depending on intellectual capital more than the brokerage sector and the insurance sector. Moreover, the findings showed significant positive relation between IC and ROA. The study also pointed out that the Malaysian financial sector relies on financial and physical capital more than intellectual capital in creating market value. Goh (2005) documented similar results who documented that Malaysian banks, which have good financial performance, have low intellectual financial coefficients.

El-Bannany (2012) analyzed the effects of the recent economic crisis on IC in UAE banking sector by the use of multiple regression analysis over 2004-2010. The findings showed significant effect of the recent economic crisis and the market structure on IC. In addition, the findings indicated that the independent variables (IT investments, size, barriers to entry, profitability, risk, age and listing age) are important and positively affect IC performance. These results are fully compatible with the findings of El-Bannany, (2008), which was conducted in the UK banking sector over the period 1999-2005.

Shih, et. al. (2010) examined correlation between knowledge creation and intellectual capital in Taiwan's banking sector. The results showed a positive impact of knowledge creation on HC, SC and customer capital. In addition, HC performance showed significant effect on customer capital and SC. Moreover, customer capital positively influence structural capital and banks with high human capital has good operational efficiency.

Mondal \& Ghosh (2012) explored the relation between IC and performance in terms of ROA, ROE and ATO for 65 Indian banks for 1999-2008. The findings highlighted significant relation between IC and firm profitability (ROA and ROE) and productivity performance (ATO). They also added that human capital has a major effect on banks performance. These findings are parallel with Kamath, (2007) that indicate that foreign banks show perfect use of HC to create value, whereas public banks rely on CE to achieve good performance.

Mention \& Bontis (2013) analyzed the relation between IC and its components with banks performance in Luxembourg and Belgium. The findings show that human capital affects banks performance directly and indirectly, whereas structural capital and relational capital both presented insignificant positive effect on banks performance.

Mavridis \& Kyrmizoglou (2005) discussed the effect of IC components on Greek banks performance. Seventeen biggest banks have been analyzed over the period 1996-1999 using a predictive (regression) analysis. The findings presented significant positive relation between value added and human capital and physical capital. Similarly, significant positive correlation has existed between value added and gross profit, net profit.

Joshi et al. (2010) explored the relation between IC ( and components) and banks' performance over the period 2005-2007 using the VAIC ${ }^{\mathrm{TM}}$ model. Significant relation between HC and value creation efficiency has been reported, where human capital efficiency is relatively higher than structural capital efficiency and capital employed efficiency. Moreover, bank size, number of employees, and shareholder equity has no influence on IC performance of Australian banks

Cabrita \& Vaz, (2005) studied the same topic for the Portuguese banking sector. The results indicated a significant and positive relation between IC and banks performance. In addition, the study found that value creation exists when the IC elements interact, which means that more the interaction among IC elements, the more value is created. This results are completely compatible with the findings of a study conducted by Cabrita \& Bontis (2008), who showed that human capital is an important part of IC that helps banks understand how can employees create value.

Holienka \& Pilková (2014) explored the impact of IC and its elements on firm performance before and after the crisis on SMEs in 10 different sectors in Slovakia by using the VAIC ${ }^{\text {TM }}$ model. Panel data consisting of 2008 (pre-crisis year), 2011 for (post-crisis year) was utilized to analyze and compare the differences in the impact of IC on SMEs performance (ROA). by using a regression model, the results showed an increasing role of IC in predicting firm's financial performance in the postcrisis period compared to the pre-crisis period. Furthermore, the results indicated that IC in generally has a significant impact on firm performance, while its components (HC, SC, and CE) showed a different result. Similarly, Radianto (2011) 
results show that IC is positively affects bank performance (ROA) over pre and post-crisis periods. The study of Sumedrea (2013) is also partly compatible with Holienka \& Pilková (2014) and Radianto (2011), where the findings indicated that in the crisis period HC and SC play a major role in companies development, while financial capital is the important factor that affect firm profitability.

In Turkey, Ozkan, et. al. (2016) studied intellectual capital and bank financial performance (ROA) relation over the period 2005 and 2014 using VAIC model. The findings indicated that HC and CE both have positive influence on financial performance of banks (ROA). However, CE is affects banks financial performance more than HC. Yalama \& Coskun (2007) reached similar results to some extent, where they found a positive impact of IC on banks profitability (ROA and ROE) in Turkish banks listed on Istanbul stock exchange (ISE) over the period 1995-2004. Calisir et al. (2011) studied the trend of intellectual capital performance in both development and investment banks in Turkey over the period 2003-2007. The results showed a decreasing trend of VAIC efficiency started in 2003, which then began to increase in 2005 and 2006.

\subsection{Research Methodology, Data Collection, Variables, and Hypothesis}

The main purpose of this study is to evaluate the intellectual capital performance and its effect on market, financial and productivity performance of the financial sector companies (Banks, Holding and investment companies, and Financial leasing companies) listed on Borsa Istanbul before and after the financial crisis.

\subsection{Data Collection and Methodology}

This study is conducted on financial companies listed on Borsa Istanbul, with a total of 44 companies including 11 banks, 29 holding and investment companies and 4 leasing and factoring companies. Data covering the period between 2004-2015 is divided into 2 periods; pre-crisis period over 2004-2007, and post-crisis period over 2010-2015.

Data is collected from several sources (i) the main source is Finnet Analysis Expert database (ii) companys' annual reports of 2004 to 2015, which are available and collected from companys; websites, in addition to Borsa Istanbul website. Companies that are lacking or missing relevant information are excluded from the sample.

\begin{tabular}{|l|l|l|}
\hline \multicolumn{2}{|l|}{ Table 1: Summary of All Variables Used in the Study } \\
\hline Variables & Abbreviation & \multicolumn{1}{l|}{ Equation } \\
\hline Independent Variables & HCE & VA/HC \\
\hline Human Capital Efficiency & SCE & SC/VA \\
\hline Structural Capital Efficiency & CEE & VA/CE (total assets minus intangible assets) \\
\hline Capital Employed Efficiency & HCE+SCE+CEE \\
\hline Value Added Intellectual Coefficient & VAIC \\
\hline Dependent Variables & PE & Market value per share/Earning per share \\
\hline Price-Earnings ratio & MB & Market Capitalization/Book Value \\
\hline Market to Book value & ROA & Net Income/Total Assets \\
\hline Return on Assets & ROE & Net Income/Total Equity \\
\hline Return on Equity & EPS & (Net Income-Preferred Dividends)/(Average Outstanding \\
& Shares) \\
\hline Earnings per Share & ATO & Total Revenue/Total Book Value \\
\hline Assets Turn Over & FAGE & Age of the company from its establishment time \\
\hline Control Variables & FSIZE & Log of firm's total assets \\
\hline Firm Age & FLEV & Total debt / Book value of total assets \\
\hline Firm Size & \multicolumn{2}{l}{} \\
\hline Firm Leverage &
\end{tabular}

Value added intellectual coefficient "VAIC" methodology was utilized to measure the impact of IC and its components (HC, $S C$, and $C E$ ) on financial performance (ROE, ROA and EPS), market performance (PE and $M B$ ), and productivity performance (ATO) on financial sector companies listed in Borsa Istanbul.

The study uses the linear regression model (OLS) to find the effect of the financial and to compare the impact of IC (independent variables) on financial firm's performance (dependent variables) between two periods; before the crisis period (2004-2007) and after the crisis period (2010-2015). 
The variables of the studies are selected by following the literature. The variables used in the study presented in Table 1.

\section{EMPIRICAL ANALYSIS}

The result of the first regression model is shown in table 2. The results show that there is a negative effect of the financial crisis on all dependent variables, which is significant on market performance variables of BM and PE. It also presented that there is no relationship between VAIC and its components and each of MB, PE, ATO, and EPS, hence there is a positive significant impact of VAIC and its component (HCE) on each of (ROA and ROE) only.

Table 2: Results of Regression of Dependent variables (MB, PE, ATO, ROA, ROE, EPS) on Control variables (Age, Fsize and LEV) and independent variables (HCE, SCE, CEE and VAIC) addition to crisis (2008 and 2009) as dummy variables

\begin{tabular}{lllllll}
\hline Variables & MB & PE & ATO & ROA & ROE & EPS \\
\hline Constant & & & & & & \\
\hline Control Variables & $1.091^{*}$ & -2.879 & -0.613 & $-0.149^{*}$ & $-12.699^{*}$ & $-1.244^{*}$ \\
\hline FAGE & & & & & & \\
FSIZE & 0.038 & 0.088 & -0.019 & -0.34 & 0.003 & 0.030 \\
FLEV & -0.049 & $0.127^{*}$ & 0.020 & $0.204^{*}$ & $0.097^{*}$ & $0.149^{*}$ \\
\hline Crisis (=1) & 0.065 & 0.003 & -0.013 & $-0.139^{*}$ & $0.105^{*}$ & -0.034 \\
\hline Independent variables & $-0.116^{*}$ & $-0.134^{*}$ & -0.016 & -0.017 & -0.005 & -0.023 \\
\hline HCE & & & & & & $0.181^{*}$ \\
SCE & -0.006 & -0.023 & 0.005 & $0.165^{*}$ & 0.018 \\
CEE & -0.009 & 0.021 & 0.011 & 0.012 & 0.029 & 0.016 \\
\hline VAIC & 0.059 & -0.022 & 0.013 & -0.013 & -0.024 & -0.048 \\
\hline F-Stat. & 0.012 & -0.012 & 0.010 & $0.166^{*}$ & $0.195^{*}$ & 0.010 \\
Prob.(F) & 26.33 & 10.30 & 753.02 & 4.76 & 24.60 & 6.63 \\
R-square & 0.000 & 0.000 & 0.000 & 0.000 & 0.000 & 0.000 \\
R-Square Change & 0.322 & 0.155 & 0.930 & 0.079 & 0.304 & 0.105 \\
\hline Obs. & 0.003 & 0.002 & 0.000 & 0.028 & 0.036 & 0.002 \\
\hline
\end{tabular}

Hints: coefficients of regression reported as standardized coefficients. *coefficient is significance at 0.05 level. VIF value for all control and independents variables are less than 3, means there is no Multicollinearity. VAIC equal positive sum of (HCE, SCE and CEE).

The result of the second regression model is shown in table 3. The findings indicate that FLEV has a significant effect on MB before the crisis, FAGE has a significant effect on PE before the crisis, and FSIZE has a significant effect on PE after the crisis. In addition, SCE has a negative significant impact on MB after crisis, and it has a positive significant impact on PE after crisis. Moreover, there is a positive significant impact of CEE on MB after the crisis.

Table 3: Results of Regression of MB and PE on Control variables (Age, Fsize and LEV) and independent variables (HCE, SCE, CEE and VAIC) before and after crisis.

\begin{tabular}{|c|c|c|c|c|c|c|}
\hline & MB & & PE & & АTO & \\
\hline Variables & $\begin{array}{l}\text { Before } \\
\text { Crisis }\end{array}$ & After Crisis & $\begin{array}{l}\text { Before } \\
\text { Crisis }\end{array}$ & After Crisis & $\begin{array}{l}\text { Before } \\
\text { Crisis }\end{array}$ & After Crisis \\
\hline Constant & $1.588^{*}$ & $1.828^{*}$ & 0.844 & $-7.406^{*}$ & $-25.053^{*}$ & $-7.480 *$ \\
\hline \multicolumn{7}{|c|}{ Control Variables } \\
\hline FAGE & 0.072 & 0.088 & $0.325^{*}$ & 0.064 & $-0.336 *$ & $-0.361^{*}$ \\
\hline FSIZE & -0.058 & -0.031 & 0.060 & $0.201 *$ & $0.500^{*}$ & $0.476^{*}$ \\
\hline FLEV & $0.250^{*}$ & 0.046 & -0.002 & -0.043 & $-0.206 *$ & -0.092 \\
\hline \multicolumn{7}{|c|}{ Independent variables } \\
\hline HCE & 0.095 & -0.007 & 0.076 & -0.074 & -0.140 & -0.028 \\
\hline SCE & -0.045 & $-0.121^{*}$ & -0.137 & $0.140^{*}$ & -0.024 & 0.001 \\
\hline CEE & 0.138 & $0.249^{*}$ & -0.023 & -0.015 & -0.049 & $-0.252^{*}$ \\
\hline VAIC & 0.113 & 0.006 & 0.041 & -0.004 & $-0.165^{*}$ & -0.081 \\
\hline F-Stat. & 2.67 & 3.55 & 3.12 & 3.27 & 10.04 & 16.45 \\
\hline
\end{tabular}




\begin{tabular}{lll|ll|lll} 
Prob.(F) & 0.018 & 0.002 & 0.007 & 0.004 & 0.000 & 0.000 \\
R-square & 0.103 & 0.077 & 0.118 & 0.071 & 0.301 & 0.277 \\
R-Square Change & 0.027 & 0.068 & 0.014 & 0.015 & 0.028 & 0.065 \\
\hline Obs. & 147 & 264 & 147 & 264 & 147 & 264 \\
\hline
\end{tabular}

Hints: coefficients of regression reported as standardized coefficients. VIF value for all control and independents variables are less than 3 , means there is no Multicollinearity. VAIC equal positive sum of (HCE, SCE and CEE). ${ }^{*}$ Significant at 0.05 level.

Regarding to ATO, there is a significant relationship with all control variables, where, FSIZE is positively affects ATO before and after crisis, FAGE and FLEV have significant negative effect on ATO before and after the crisis. On the other hand, VAIC in general, has a significant negative impact on ATO before the crisis, while CEE has a significant negative impact on ATO after the crisis.

The results of table 4 show that, FLEV has a negative significant effect on ROA before and after the crisis, and FSIZE has a positive significant effect on ROA after the crisis. Regarding to ROE, it has a positive significant relationship with FLEV before the crisis and the same relation with FSIZE and FLEV after the crisis. Regarding to EPS variable it has a positive significant relation with FSIZE before and after the crisis, also it has a negative significant relation with FLEV before the crisis. Moreover, VAIC in general, has positive significant impact on ROA after crisis, and the same influence on ROA and ROE before and after crisis.

$\mathrm{HC}$ is positively and significantly affect ROA after the crisis, and the same effect on ROA and ROE before and after crisis. In addition, SCE has a positive and significant with only ROE after the crisis. Regarding to EPS, there is no significant relationship with IC or any of its components neither before nor after the crisis.

Table 4: Results of Regression of ROA, ROE, and EPS on Control variables (Age, Fsize and LEV) and independent variables (HCE, SCE, CEE and VAIC) before and after crisis.

\begin{tabular}{lll|ll|ll}
\hline \multicolumn{2}{l}{ ROA } & & ROE & & EPS \\
\hline Variables & $\begin{array}{l}\text { Before } \\
\text { Crisis }\end{array}$ & After Crisis & $\begin{array}{l}\text { Before } \\
\text { Crisis }\end{array}$ & After Crisis & $\begin{array}{l}\text { Before } \\
\text { Crisis }\end{array}$ & After Crisis \\
\hline Constant & 0.011 & $-0.206^{*}$ & -12.640 & $-27.484^{*}$ & -0.950 & $-1.932^{*}$ \\
\hline Control Variables & & & & & & 0.060 \\
\hline FAGE & -0.024 & -0.025 & -0.058 & 0.045 & -0.001 & $0.176^{*}$ \\
FSIZE & 0.055 & $0.236^{*}$ & 0.132 & $0.192^{*}$ & $0.174^{*}$ & -0.026 \\
FLEV & $-0.242^{*}$ & $-0.31^{*}$ & $0.312^{*}$ & $0.131^{*}$ & $-0.201^{*}$ & \\
\hline Independent variables & & & & & & 0.025 \\
\hline HCE & 0.034 & $0.199^{*}$ & $0.279^{*}$ & $0.249^{*}$ & -0.082 & 0.035 \\
SCE & 0.052 & 0.029 & 0.007 & $0.124^{*}$ & 0.098 & -0.040 \\
CEE & -0.009 & -0.005 & -0.029 & -0.018 & -0.020 & 0.034 \\
\hline VAIC & 0.062 & $0.203^{*}$ & $0.282^{*}$ & $0.311^{*}$ & -0.045 & 2.09 \\
\hline F-Stat. & 1.59 & 4.30 & 5.16 & 11.13 & 1.59 & 0.054 \\
Prob.(F) & 0.155 & 0.000 & 0.000 & 0.000 & 0.155 & 0.047 \\
R-square & 0.064 & 0.091 & 0.181 & 0.206 & 0.064 & 0.004 \\
R-Square Change & 0.006 & 0.045 & 0.075 & 0.105 & 0.008 & 264 \\
\hline Obs. & 147 & 264 & 147 & 264 & 147 & \\
\hline
\end{tabular}

Hints: coefficients of regression reported as standardized coefficients. VIF value for all control and independents variables are less than 3, means there is no Multicollinearity. VAIC equal positive sum of (HCE, SCE and CEE). * Significant at 0.05 level.

\section{CONCLUSION}

The objective of this study is to investigate intellectual capital and its components (human capital, structural capital and capital employed) relation on the basis of market, financial and productivity performance of the financial sector before and after financial crisis. The paper was conducted using data from 44 listed companies on Borsa Istanbul. Pulic's method VAIC was used as a measurement of intellectual capital. market performance was represented by (MB and PE ratios), (ROA, ROE and EPS ratios) were used as indicators of financial performance and ATO ratio was used as indicator of productivity performance. 
Human capital shows more effective on value creation than structural capital and capital employed for the study period before and after financial crisis. HCE indicates a positive significant relationship with ROA after the crisis and with ROE before and after the crisis.

SCE has a positive significant relation with PE and ROE after the crisis and a negative significant association with MB after the crisis. Regarding to CEE, the results show that it has only a positive significant impact on $M B$ after the crisis and a negative significant influence on ATO after the crisis. Generally, VAIC has a negative significant relationship with ATO before the crisis and has a positive association with ROA after the crisis, in addition to a positive significant influence of ROE before and after the crisis.

The findings of the study are consistent with the previous studies e.g. Bontis et al., (2000); Muhammad \& Ismail, (2014); Goh (2005); El-Bannany, (2012); Shih et al., (2010); Mondal \& Ghosh, (2012); Mention \& Bontis, (2013); Joshi et al., (2010); Yalama \& Coskun, (2007). And partly consistent with the previous studies e.g. Holienka \& Pilková, (2014); Sumedrea, (2013) and Radianto, (2011).

This study has limitations due to the lack of data sources, where there are many missing values during the study's period, hence, the external validity was very weak. Therefore, the findings cannot be generalized for other sectors because of the differences in the nature of those sectors.

Suggestions for future research would be applying the study on other sectors, comparing between financial sectors in the region, and comparing between VAIC as measurement of intellectual capital with other measurements of intellectual capital.

\section{REFERENCES}

Abdulsalam, F., Al-Qaheri, H., \& Al-Khayyat, R. (2011). The Intellectual Capital Performance of KuwaitiBanks: An Application of vaicTM1 Model. iBusiness, 03(01), 88-96.

Al-Zoubi, M. R. (2013). The Impact of Intellectual Capital on SWOT Analysis among Jordanian Banking Industry" Empirical Study." International Journal of Business and Social Science, 4(2).

Basso, L. F. C., Kimura, H., \& da Aguiar, J. F. (2010). Intellectual capital and value creation in the production and assembly of vehicles and auto-parts sector in Brazil: a panel data analysis. Journal of Modern Accounting and Auditing, 6(8), 15

Bontis, N. (1998). Intellectual capital: an exploratory study that develops measures and models. Management Decision, 36(2), 63-76.

Bontis, N. (2001). Assessing knowledge assets: a review of the models used to measure intellectual capital. International Journal of Management Reviews, 3(1), 41-60.

Bontis, N., Chua Chong Keow, W., \& Richardson, S. (2000). Intellectual capital and business performance in Malaysian industries. Journal of Intellectual Capital, 1(1), 85-100.

Bozbura, F. T. (2004). Measurement and application of intellectual capital in Turkey. The Learning Organization, 11(4/5), 357-367.

Brooking, A. (1996). Intellectual Capital: Core Assets for the Third Millennium Enterprise. London, UK: Thomson Business Press.

Cabrita, M. D. R., \& Bontis, N. (2008). Intellectual capital and business performance in the Portuguese banking industry. International Journal of Technology Management, 43(1-3), 212-237.

Cabrita, M. D. R., \& Vaz, J. L. (2005). Intellectual Capital and Value Creation: Evidence from the Por-tuguese Banking Industry. Electronic Journal of Knowledge Management, 4(1), 11-20.

Calisir, F., Altin Gumussoy, C., Cirit, F., Yorulmaz, E., \& Bayraktaroglu, A. E. (2010). Intellectual Capital in Turkish Private Banks (pp. 189194). SciTePress - Science and and Technology Publications.

Calisir, F., Gumussoy, C. A., Cirit, F., \& Bayraktaroglu, A. E. (2011). Intellectual capital in development and investment banks of Turkey. In International Conference on Industrial Engineering and Operations Management, Kuala Lumpur (pp. 22-24).

Chang, W. S. (2010). The Different Proportion of IC Components and Firms' Market Performance: Evidence from Taiwan. The International Journal of Business and Finance Research, 4(4), 121-134.

Goh, P. (2005). Intellectual capital performance of commercial banks in Malaysia. Journal of Intellectual Capital, 6(3), 385-396.

Chen, M., Cheng, S., \& Hwang, Y. (2005). An empirical investigation of the relationship between intellectual capital and firms' market value and financial performance. Journal of Intellectual Capital, 6(2), 159-176.

Edvinsson, L. (1997). Developing intellectual capital at Skandia. Long Range Planning, 30(3), 366-373. 
Edvinsson, L., \& Malone, M. S. (1997). Intellectual Capital: Realizing Your Company's True Value by Finding Its Hidden Brainpower (1st edition). New York: HarperBusiness.

El-Bannany, M. (2008). A study of determinants of intellectual capital performance in banks: the UK case. Journal of Intellectual Capital, $9(3), 487-498$.

El-Bannany, M. (2012). Global financial crisis and the intellectual capital performance of UAE banks. Journal of Human Resource Costing \& Accounting, 16(1), 20-36.

Holienka, M., \& Pilková, A. (2014). Impact of Intellectual Capital and its Components on Firm Performance Before and After Crisis. Electronic Journal of Knowledge Management, 12(4).

Joshi, M., Cahill, D., \& Sidhu, J. (2010). Intellectual capital performance in the banking sector: An assessment of Australian owned banks. Journal of Human Resource Costing \& Accounting, 14(2), 151-170.

Jurczak, J. (2008). Intellectual Capital Measurement Methods. Economics and Organization of Enterprise, 1(1), 37-45.

Kamath, G. B. (2007). The intellectual capital performance of the Indian banking sector. Journal of Intellectual Capital, 8(1), 96-123.

Khalique, M., Shaari, N., Abdul, J., \& Isa, A. H. B. M. (2011). Intellectual capital and its major components.

Kujansivu, P., \& Lönnqvist, A. (2007). Investigating the value and efficiency of intellectual capital. Journal of Intellectual Capital, 8(2), 272287.

Lev, B. (2001). Intangibles: Management, Measurement and Reporting. Brookings Institution Press.

Luthy, D. H. (1998). Intellectual capital and its measurement. In Proceedings of the Asian Pacific Interdisciplinary Research in Accounting Conference (APIRA), Osaka, Japan (pp. 16-17). Citeseer.

Mårtensson, M. (2000). A critical review of knowledge management as a management tool. Journal of Knowledge Management, 4(3), 204216.

Mavridis, D. G. (2004). The intellectual capital performance of the Japanese banking sector. Journal of Intellectual Capital, 5(1), 92-115.

Mavridis, D. G., \& Kyrmizoglou, P. (2005). Intellectual capital performance drivers in the Greek banking sector. Management Research News, 28(5), 43-62.

Mayo, A. (2001). Human Value of the Enterprise. Nicholas Brealey Publishing London.

Meihami, B., Varmaghani, Z., \& Meihami, H. (2013). Role of Intellectual Capital on Firm Performance (Evidence from Iranian Companies). International Letters of Social and Humanistic Sciences, 12, 43-50.

Mention, A., \& Bontis, N. (2013). Intellectual capital and performance within the banking sector of Luxembourg and Belgium. Journal of Intellectual Capital, 14(2), 286-309.

Mondal, A., \& Ghosh, S. K. (2012). Intellectual capital and financial performance of Indian banks. Journal of Intellectual Capital, 13(4), 515530 .

Moradi, M., Saeedi, M., Hajizadeh, H., \& Mohammadi, M. (2013). The Influence of Intellectual Capital on the Improvement of Companies' Financial Performance. International Journal of Economics, Business and Finance, 1(5), 120-139.

Mosavi, S. A., Nekoueizadeh, S., \& Ghaedi, M. (2012). A study of relations between intellectual capital components, market value and finance performance. African Journal of Business Management, 6(4).

Muhammad, N. M. N., \& Ismail, M. K. A. (2009). Intellectual capital efficiency and firm's performance: study on Malaysian financial sectors. International Journal of Economics and Finance, 1(2), 206

Muhammad, N. M. N., \& Ismail, M. K. A. (2014). Intellectual capital efficiency and firm's performance: Study on Malaysian Financial Sectors. International Journal of Economics and Finance, 1(2), p206.

Ozkan, N., Cakan, S., \& Kayacan, M. (2016). Intellectual Capital and Financial Performance: A Study of the Turkish Banking Sector. Borsa Istanbul Review.

Peppard, J., \& Rylander, A. (2001). Using an intellectual capital perspective to design and implement a growth strategy: the case of APiON. European Management Journal, 19(5), 510-525.

Pulic, A. (1998). Measuring the performance of intellectual potential in knowledge economy. In 2nd McMaster Word Congress on Measuring and Managing Intellectual Capital by the Austrian Team for Intellectual Potential.

Pulic, A. (2000). VAIC ${ }^{\mathrm{TM}}$-an accounting tool for IC management. International Journal of Technology Management, 20(5-8), 702-714.

Pulic, A. (2004). Intellectual capital - does it create or destroy value? Measuring Business Excellence, 8(1), 62-68.

Pulic, A. (2008). The principles of intellectual capital efficiency-A brief description. Croatian Intellectual Capital Center, Zagreb, 76. 
Radianto, W. E. (2011). The influence of intellectual capital on banking industry performance: a case in indonesia stock exchange before and after the 2008 global financial crisis. Asia Pacific Journal of Accounting and Finance, 2, 1.

Rehman, M. U., Ahmed, K., \& Qazi, A. Q. (2014). A study of causality between disintegrated intellectual capital and firm performance.

Rehman, W. U., Rehman, H. U., Usman, M., \& Asghar, N. (2012). A Link of intellectual capital performance with corporate performance: comparative study from banking sector in Pakistan. International Journal of Business and Social Science, 3(12).

Roos, G., \& Roos, J. (1997). Measuring your company's intellectual performance. International Journal of Strategic Management, Long Range Planning, 30(3), 413-426.

Roos, G., Roos, J., Dragonetti, N. C., \& Edvinsson, L. (1997). Intellectual Capital: Navigating in the New Business Landscape. London, UK: Macmillan Publications.

Shih, K., Chang, C., \& Lin, B. (2010). Assessing knowledge creation and intellectual capital in banking industry. Journal of Intellectual Capital, 11(1), 74-89.

Stewart, T. (1997). Intellectual Capital: The New Wealth Of Organizations (illustrated, reprint). Business Digest, New York: Doubleday / Currency.

Stewart, T. (2002). The Wealth of Knowledge: Intellectual Capital and the Twenty-First Century Organization. London: Nicholas Brealey Publishing Limited.

Sullivan, P. H. (1999). Profiting from intellectual capital. Journal of Knowledge Management, 3(2), 132-143.

Sumedrea, S. (2013). Intellectual Capital and Firm Performance: A Dynamic Relationship in Crisis Time. Procedia Economics and Finance, 6, 137-144.

Sveiby, K. E. (1997). The new organizational wealth: managing \& measuring knowledge-based assets (1st ed). San Francisco: BerrettKoehler Publishers.

Sydler, R., Haefliger, S., \& Pruksa, R. (2014). Measuring intellectual capital with financial figures: Can we predict firm profitability? European Management Journal, 32(2), 244-259.

Tayles, M., Pike, R. H., \& Sofian, S. (2007). Intellectual capital, management accounting practices and corporate performance: Perceptions of managers. Accounting, Auditing \& Accountability Journal, 20(4), 522-548.

Yalama, A., \& Coskun, M. (2007). Intellectual capital performance of quoted banks on the Istanbul stock exchange market. Journal of Intellectual Capital, 8(2), 256-271.

Zeghal, D., \& Maaloul, A. (2010). Analysing value added as an indicator of intellectual capital and its consequences on company performance. Journal of Intellectual Capital, 11(1), 39-60. 